\title{
Influence of Ripening Agent(s) on Post-Harvest Physiology and Enzymatic Activity of Mango (Mangifera indica) cv. Dashehari
}

\author{
Pramila Kumari $^{1}$, Shalini Pilania ${ }^{1 *}$, D.K. Sarolia ${ }^{2}$, Virendra Singh ${ }^{1}$, \\ L.N. Mahawer ${ }^{1}$ and Seema Gupta ${ }^{1}$ \\ ${ }^{1}$ Department of Horticulture, RCA, MPUAT, Udaipur (Rajasthan), India \\ ${ }^{2}$ Division of Crop Production, ICAR- CIAH, Bikaner (Rajasthan), India \\ *Corresponding author
}

\section{A B S T R A C T}

\begin{tabular}{|c|c|}
\hline Keywords & Dashehari. For this mangoes were treated with ripening agent(s) in fourteen \\
\hline $\begin{array}{l}\text { Mango, Post- } \\
\text { harvest physiology, } \\
\text { Enzymatic activity, } \\
\text { Ambient, Ripening } \\
\text { agent(s). }\end{array}$ & $\begin{array}{l}\text { configuration viz., without treatment }\left(T_{0}\right) \text {, ethephon }\left(T_{1}\right) \text {, dried plash leaves }\left(T_{2}\right) \text {, } \\
\text { wet kachnar leaves }\left(T_{3}\right) \text {, wet amaltas leaves }\left(T_{4}\right) \text {, wheat straw }\left(T_{5}\right) \text {, rice straw }\left(T_{6}\right) \text {, } \\
\text { newspaper }\left(T_{7}\right) \text {, white paper }\left(T_{8}\right) \text {, tissue Paper }\left(T_{9}\right) \text {, brown paper bag }\left(T_{10}\right) \text {, wheat } \\
\text { grain }\left(T_{11}\right) \text {, jute bag }\left(T_{12}\right) \text {, and cardamom }\left(T_{13}\right) \text {, upto six days, replicated four times }\end{array}$ \\
\hline Articl & ondition treatment $T_{2}$ (Dried plash le \\
\hline $\begin{array}{l}\text { Accepted: } \\
28 \text { October } 2017 \\
\text { Available Online: } \\
10 \text { December } 2017\end{array}$ & $\begin{array}{l}\text { nysiology and enzymatic activity attributes viz., Ripening Index, Ethylene, } \\
\text { espiration rate, Polygalacturonase (PG), Pectin methyl esterase (PME), value } \\
\text { gher and Physiological loss of weight lower during the ripening period (up to } 6 \\
\text { ays). }\end{array}$ \\
\hline
\end{tabular}

\section{Introduction}

Mango (Mangifera indica L.) known as "King of all fruits" is one of the oldest and choicest tropical fruits of the world. It has delicious taste, excellent flavor and attractive fragrance, it is rich in vitamins $A$ and $C$. It is a climacteric fruit, exhibiting a climacteric pattern of respiration and an increase in ethylene production during ripening (Cua and Lizada, 1990 and Reddy and Srivastava, 1999). The initiation of ethylene production within the fruit triggers and coordinates the changes that occur during ripening. These include: (i) flesh colour greenish yellow to yellow to orange in all cultivars; (ii) skin colour from green to yellow in some cultivars; (iii) chlorophyll decreases and carotenoid content increases; (iv) flesh firmness decreases and juiciness increases; (v) conversion of starch into sugars; (vi) total soluble solids content increases; (vii) titratable acidity decreases; (viii) characteristic aroma volatiles increase; (ix) $\mathrm{CO}_{2}$ production rate increases from about 4050 to $160-200 \mathrm{mg} \mathrm{kg}^{-1} \mathrm{~h}^{-1}$ at $20^{\circ} \mathrm{C}$ and (x) ethylene production rate increases from about 0.1-0.2 to $1-3 \mu \mathrm{L} \mathrm{kg}{ }^{-1} \mathrm{~h}^{-1}$ at $20^{\circ} \mathrm{C}$ (Yahia, 2011). Respiration patterns and ripening behavior vary among cultivars, with different 
climatic conditions and growing locations (Krishnamurthy and Subramanyam, 1970). The respiratory peak in 'Alphonso' mangoes harvested mature-green occurs 5 days after harvest, and the fruit ripens within 7 to 8 days (Karmarkar and Joshi, 1941), while, in 'Kent' and 'Haden' mangoes the peak occurs on days 9 and 11, respectively (Burg and Burg, 1962), and in 'Pairi' mangoes on day 9 (Krishnamurthy and Subramanyam, 1970). These differences are normal due to differences in location, climatic conditions, orchard and tree conditions and especially postharvest conditions used in the different studies. The rise in the climacteric respiration in 'Dashehari', 'Amarpali' and 'Rataul' mangoes coincide with the highest level of sucrose and polygalacturonase (PG) activity in ripening fruit (Kalra and Tandon, 1983). Further, with the rapid development of fruit trade, most of the fruit sellers are using ripening agents such as calcium carbide which is extremely hazardous to the human body as it contains traces of arsenic and phosphorus. Similarly, ethrel is another ripening agent used for fruits. On dipping the mature fruits in ethrel, it enters the fruits cell, releases ethylene and hastens the ripening process. However, use of such ripening agent(s) decrease on the nutritive value as well as have negative impact on food safety $\&$ health security and it has also been observed that these ripened fruit have shorter shelf life. Keeping in view, the above mentioned facts present study is proposed to assess whether the organic agents can also hasten the ripening of mango similar to the inorganic organic ripening agents and can be exploited as natural and safe mode of fruit ripening.

\section{Materials and Methods}

Mangoes were treated with different ripening agents such as $\left(\mathrm{T}_{0}\right)$ Control without treatment, $\left(\mathrm{T}_{1}\right)$ ethephon 1000ppm $(10 \mathrm{ml}$ in 1 litre water) was sprayed with pump pressure sprayer, $\left(\mathrm{T}_{2}\right)$ plash leaves harvested in morning and dried under shade for five days (800 gm), $\left(\mathrm{T}_{3}\right)$ wet kachnar leaves collected in morning $(1.50 \mathrm{~kg}),\left(\mathrm{T}_{4}\right)$ wet amaltas leaves were collected in morning $(1.50 \mathrm{~kg}),\left(\mathrm{T}_{5}\right)$ wheat straw $(2.5 \mathrm{~kg}),\left(\mathrm{T}_{6}\right)$ rice straw $(700 \mathrm{gm})$, $\left(\mathrm{T}_{7}\right)$ newspaper $(250 \mathrm{gm}),\left(\mathrm{T}_{8}\right)$ white paper $(160 \mathrm{gm}),\left(\mathrm{T}_{9}\right)$ tissue paper $(110 \mathrm{gm}),\left(\mathrm{T}_{10}\right)$ brown paper bag (210 gm), $\left(\mathrm{T}_{11}\right)$ wheat grain $(4 \mathrm{~kg}),\left(\mathrm{T}_{12}\right)$ jute bag $(3.25 \mathrm{~kg})$, and $\left(\mathrm{T}_{13}\right)$ Cardamom (4 in number) for $3 \mathrm{~kg}$ mangoes having size approx 150 gm per replicae per treatment were layered alternately in a CFB Box. However, for four replications, $12 \mathrm{~kg}$ mangoes each having size approximately 150 gm were used per treatment. Therefore treated $168 \mathrm{~kg}$ mangoes fruits were packed in fifty six corrugated fibre boards. All boxes were tagged as per treatment and stored under ambient condition. Observations were recorded daily till fruit ripened upto 6 days by the following methods.

Physiological Loss In Weight (\%) by measuring initial and final weight, Moisture (\%)AOAC (1980), Firmness (Newton) by Texture Analyzer, Respiration Rate (ml $\mathrm{Co}_{2} \mathrm{~kg}^{-1} \mathrm{~h}^{-1}$ ) by Head Space Gas Analyzer, Ethylene Production (ppm) by Ethylene Analyzer, Ripening Index (\%) Va'sqezCaicedo et al., (2005), Polygalacturonase (PG) $\left(\mu \mathrm{gPGN} \mathrm{min}^{-1}\right.$ ) Zainon and Brady (1982), Pectin methyl esterase (PME) $\left(\mathrm{A}_{620} \mathrm{~min}^{-1}\right)$ Hagerman and Austin (1986)

\section{Results and Discussion}

\section{Physiological loss of weight and Moisture content}

It is evident from the data (Table 1) that physiological loss of weight of mangoes was increased with the advancement of ripening in all the treatments. The maximum physiological loss of weight recorded in the $\mathrm{T}_{1}(27 \%)$ followed by $\mathrm{T}_{11}(25.12 \%)$ and 
minimum in $T_{2}(10.12 \%)$ on $6^{\text {th }}$ day of ripening period. Weight loss is mainly related to respiration through skin, transpiration and metabolic process in the fruit. The rate of water loss depends on the water pressure gradient between the fruit tissue and the surrounding atmosphere in strawberry (Hernandez-Munoz et al., 2008), in guava (Wijewardane, 2013) and in banana fruit (Rahaman and Bishop, 2013). Similarly, moisture content was increased with the advancement of ripening in all the treatments. The maximum moisture content recorded in the $\mathrm{T}_{1}$ (Ethephon) $(90.45 \%)$ and minimum in $\mathrm{T}_{0}(69.25 \%)$ on $6^{\text {th }}$ day of ripening period.

\section{Firmness and ripening index}

The results indicate that the Firmness of ripened mango was decreased with the advancement of ripening (Table 2). On $6^{\text {th }}$ day minimum firmness (3.50 Newton) was recorded in the treatment $\mathrm{T}_{1}$ (Ethephon) followed by 7.50 Newton in $\mathrm{T}_{2}$ (Newspaper) and maximum (20.00 Newton) was in $T_{0}$ (without treatment). Fruit firmness was gradually decreased from the initial stage to the final stage of ripening. This decrease was more in the treated fruits than in the control fruits. Decreasing fruit firmness might be associated with fruit softening which in coincide with the report of (Gill et al., 2015).

In ripening mango, sharp physio-chemical changes that occur are softening of the fruit, change in odour and flavour, increase in sugar content, reduction in organic acids, and formation of pigments, especially carotenoids and ripening index on $6^{\text {th }}$ day was maximum 7.24 in $\mathrm{T}_{2}$ (Dried plash leaves) and lowest 6.55 in $T_{1}$ (Ethephon). Increase in ripening index during post-harvest storage was mainly due to decrease in acidity and increase in TSS. Sugar: acid ratio serves as an index of degree of ripeness and hence determines the flavour of the fruit.

Table.1 Effect of ripening agent(s) on physiological loss of weight and moisture content of mango $\mathrm{cv}$. Dhasheri during ripening time

\begin{tabular}{|l|c|c|c|c|c|c|c|c|c|c|c|c|}
\hline \multirow{2}{*}{ Treatment } & \multicolumn{10}{|c|}{ Mipening time (days) } \\
\cline { 2 - 15 } & \multicolumn{9}{|c|}{ Physiological loss of weight $\%$ Moisture $(\%)$} \\
\hline & 1 & 2 & 3 & 4 & 5 & 6 & 1 & 2 & 3 & 4 & 5 & 6 \\
\hline $\mathrm{T}_{0}$ (Without treatment) & 4.95 & 8.48 & 16.66 & 17.26 & 18.77 & 22.89 & 55.60 & 57.14 & 59.45 & 62.14 & 65.25 & 69.25 \\
\hline $\mathrm{T}_{1}$ (Ethephon) & 6.02 & 9.45 & 14.78 & 17.44 & 21.00 & 27.03 & 67.95 & 69.00 & 71.75 & 83.45 & 86.75 & 90.45 \\
\hline $\mathrm{T}_{2}$ (Dried plash leaves) & 0.24 & 3.32 & 4.82 & 7.42 & 9.81 & 10.12 & 64.54 & 69.10 & 75.65 & 79.15 & 82.45 & 86.15 \\
\hline $\mathrm{T}_{3}$ (Wet kachnar leaves) & 0.82 & 4.98 & 7.93 & 10.00 & 12.61 & 13.00 & 64.00 & 71.95 & 76.45 & 78.45 & 81.95 & 85.75 \\
\hline $\mathrm{T}_{4}$ (Wet Amaltas leaves) $)$ & 0.96 & 5.41 & 9.10 & 10.24 & 12.62 & 12.95 & 64.00 & 71.00 & 77.00 & 77.94 & 80.14 & 85.01 \\
\hline $\mathrm{T}_{5}$ (Wheat straw) & 5.24 & 8.49 & 10.24 & 14.66 & 15.12 & 18.75 & 57.45 & 61.00 & 65.45 & 76.12 & 70.45 & 73.45 \\
\hline $\mathrm{T}_{6}$ (Rice straw) & 4.77 & 10.5 & 14.81 & 17.67 & 20.78 & 23.18 & 58.17 & 62.25 & 64.24 & 69.45 & 72.70 & 75.25 \\
\hline $\mathrm{T}_{7}$ (News paper) & 4.24 & 9.02 & 16.59 & 18.02 & 19.09 & 22.85 & 61.75 & 67.45 & 72.45 & 78.25 & 82.14 & 88.14 \\
\hline $\mathrm{T}_{8}$ (White paper) & 3.28 & 7.12 & 10.11 & 13.56 & 16.81 & 20.38 & 59.00 & 64.40 & 69.25 & 73.14 & 75.45 & 79.35 \\
\hline $\mathrm{T}_{9}$ (Tissue paper) & 6.12 & 8.12 & 13.45 & 18.25 & 21.45 & 23.50 & 59.00 & 66.00 & 70.00 & 74.00 & 78.00 & 82.45 \\
\hline $\mathrm{T}_{10}$ (Brown paper bag) & 5.38 & 11.21 & 14.51 & 17.46 & 18.18 & 23.65 & 60.00 & 65.50 & 71.00 & 76.45 & 81.70 & 85.80 \\
\hline $\mathrm{T}_{11}$ (Wheat grain) & 4.98 & 10.12 & 11.56 & 17.45 & 20.12 & 25.12 & 57.12 & 62.50 & 64.00 & 68.00 & 71.90 & 77.75 \\
\hline $\mathrm{T}_{12}$ (Jute bag) & 3.24 & 5.94 & 10.12 & 12.39 & 18.58 & 19.17 & 55.70 & 56.14 & 58.12 & 61.25 & 65.01 & 70.85 \\
\hline $\mathrm{T}_{13}$ (Cardamom) & 5.23 & 9.45 & 14.22 & 17.55 & 20.81 & 24.62 & 63.21 & 67.45 & 72.75 & 79.45 & 82.45 & 84.15 \\
\hline $\mathrm{SEm} \pm$ & 0.26 & 0.59 & 0.08 & 0.10 & 0.21 & 0.28 & 0.38 & 0.47 & 0.48 & 0.51 & 1.00 & 1.03 \\
\hline $\mathrm{CD}$ (P=0.01) & 1.10 & 0.22 & 0.31 & 0.39 & 0.81 & 1.08 & 1.48 & 1.80 & 1.83 & 1.97 & 3.82 & 3.94 \\
\hline
\end{tabular}


Table.2 Effect of ripening agent(s) on firmness and ripening index of mango cv. Dhasheri during ripening time

\begin{tabular}{|c|c|c|c|c|c|c|c|c|c|c|c|c|}
\hline \multirow[t]{3}{*}{ Treatment } & \multicolumn{12}{|c|}{ Ripening time (days) } \\
\hline & \multicolumn{6}{|c|}{ Firmness (Newton) } & \multicolumn{6}{|c|}{ Ripening Index } \\
\hline & 1 & 2 & 3 & 4 & 5 & 6 & 1 & 2 & 3 & 4 & 5 & 6 \\
\hline $\mathrm{T}_{0}$ (Without treatment) & 36.00 & 32.50 & 28.00 & 25.00 & 22.00 & 20.00 & 6.42 & 6.49 & 6.70 & 6.74 & 6.77 & 6.78 \\
\hline $\mathrm{T}_{1}$ (Ethephon) & 24.00 & 18.00 & 13.00 & 10.00 & 7.00 & 3.50 & 6.60 & 6.83 & 7.10 & 7.41 & 7.14 & 6.55 \\
\hline $\mathrm{T}_{2}$ (Dried plash leaves) & 34.00 & 29.00 & 23.00 & 17.00 & 12.00 & 8.50 & 6.42 & 6.49 & 6.70 & 6.84 & 7.17 & 7.24 \\
\hline $\mathrm{T}_{3}$ (Wet kachnar leaves) & 33.00 & 30.00 & 24.00 & 19.00 & 13.50 & 9.00 & 6.44 & 6.49 & 6.66 & 6.83 & 7.12 & 7.16 \\
\hline $\mathrm{T}_{4}($ Wet Amaltas leaves $)$ & 32.50 & 30.50 & 26.00 & 20.50 & 14.00 & 9.00 & 6.48 & 6.55 & 6.75 & 6.88 & 7.09 & 7.19 \\
\hline $\mathrm{T}_{5}($ Wheat straw $)$ & 32.00 & 29.00 & 28.00 & 26.00 & 21.00 & 17.00 & 6.42 & 6.52 & 6.88 & 7.03 & 7.07 & 7.10 \\
\hline $\mathrm{T}_{6}($ Rice straw $)$ & 31.00 & 27.00 & 25.50 & 23.50 & 22.50 & 18.00 & 6.34 & 6.43 & 6.60 & 6.80 & 7.05 & 7.07 \\
\hline $\mathrm{T}_{7}$ (News paper) & 31.00 & 28.00 & 25.50 & 21.00 & 14.00 & 7.50 & 6.51 & 6.63 & 6.88 & 7.11 & 7.13 & 7.13 \\
\hline $\mathrm{T}_{8}$ (White paper) & 33.00 & 30.00 & 27.50 & 23.00 & 19.00 & 16.00 & 6.49 & 6.54 & 6.84 & 6.91 & 7.01 & 7.02 \\
\hline $\mathrm{T}_{9}$ (Tissue paper) & 34.00 & 32.00 & 28.00 & 24.00 & 18.00 & 13.00 & 6.39 & 6.40 & 6.69 & 6.85 & 6.93 & 6.97 \\
\hline $\mathrm{T}_{10}($ Brown paper bag $)$ & 33.00 & 29.50 & 26.00 & 22.00 & 15.00 & 11.00 & 6.40 & 6.46 & 6.73 & 6.78 & 6.87 & 6.89 \\
\hline $\mathrm{T}_{11}($ Wheat grain $)$ & 31.00 & 27.50 & 22.50 & 18.00 & 16.00 & 12.50 & 6.41 & 6.47 & 6.62 & 6.67 & 6.73 & 6.76 \\
\hline $\mathrm{T}_{12}$ (Jute bag) & 36.00 & 34.00 & 27.00 & 23.50 & 22.00 & 18.00 & 6.43 & 6.45 & 6.53 & 6.65 & 6.69 & 6.70 \\
\hline $\mathrm{T}_{13}($ Cardamom $)$ & 35.00 & 28.00 & 25.00 & 19.00 & 14.00 & 10.00 & 6.59 & 6.61 & 6.88 & 6.90 & 6.99 & 7.10 \\
\hline $\mathrm{SEm} \pm$ & 0.21 & 0.25 & 0.17 & 0.14 & 0.20 & 0.16 & 0.03 & 0.04 & 0.04 & 0.06 & 0.10 & 0.08 \\
\hline $\mathrm{CD}(\mathrm{P}=0.01)$ & 0.80 & 0.85 & 0.65 & 0.53 & 0.79 & 0.61 & 0.12 & 0.18 & 0.17 & 0.22 & 0.39 & 0.33 \\
\hline
\end{tabular}

Table.3 Effect of ripening agent(s) on ethylene and respiration rate of mango cv. Dhasheri during ripening time

\begin{tabular}{|c|c|c|c|c|c|c|c|c|c|c|c|c|}
\hline \multirow[t]{3}{*}{ Treatment } & \multicolumn{12}{|c|}{ Ripening time (days) } \\
\hline & \multicolumn{6}{|c|}{ Ethylene (ppm) } & \multicolumn{6}{|c|}{ Respiration rate $\left(\mathrm{ml} \mathrm{CO}_{2} \mathrm{~kg}^{-1} \mathrm{~h}^{-1}\right)$} \\
\hline & 1 & 2 & 3 & 4 & 5 & 6 & 1 & 2 & 3 & 4 & 5 & 6 \\
\hline $\mathrm{T}_{0}$ (Without treatment) & 3 & 10 & 15 & 18 & 20 & 24 & 16.684 & 24.532 & 39.687 & 51.359 & 65.691 & 66.987 \\
\hline $\mathrm{T}_{1}$ (Ethephon) & 50 & 74 & 95 & 110 & 160 & 94 & 67.24 & 79.626 & 86.542 & 92.639 & 58.847 & 32.528 \\
\hline $\mathrm{T}_{2}$ (Dried plash leaves) & 38 & 68 & 88 & 98 & 136 & 151 & 47.017 & 80.637 & 99.09 & 101.921 & 108.544 & 117.846 \\
\hline $\mathrm{T}_{3}$ (Wet kachnar leaves) & 48 & 74 & 94 & 105 & 111 & 129 & 39.687 & 83.418 & 97.599 & 100.006 & 108.666 & 110.794 \\
\hline $\mathrm{T}_{4}$ (Wet Amaltas leaves) & 36 & 69 & 74 & 80 & 102 & 134 & 39.813 & 68.365 & 94.888 & 102.803 & 108.729 & 113.752 \\
\hline $\mathrm{T}_{5}$ (Wheat straw) & 6 & 19 & 36 & 49 & 59 & 62 & 20.602 & 32.356 & 47.321 & 60.263 & 64.156 & 74.521 \\
\hline $\mathrm{T}_{6}($ Rice straw $)$ & 11 & 24 & 39 & 46 & 56 & 64 & 25.025 & 40.698 & 55.738 & 68.251 & 76.188 & 78.868 \\
\hline $\mathrm{T}_{7}($ News paper $)$ & 19 & 37 & 52 & 87 & 102 & 128 & 52.578 & 69.767 & 76.795 & 82.912 & 88.727 & 95.551 \\
\hline $\mathrm{T}_{8}$ (White paper) & 4 & 9 & 16 & 29 & 49 & 61 & 21.992 & 49.899 & 58.696 & 64.51 & 71.638 & 78.109 \\
\hline $\mathrm{T}_{9}$ (Tissue paper) & 6 & 16 & 21 & 34 & 50 & 79 & 30.334 & 42.467 & 50.152 & 75.581 & 81.143 & 87.361 \\
\hline $\mathrm{T}_{10}($ Brown paper bag $)$ & 12 & 23 & 42 & 54 & 79 & 85 & 51.314 & 59.151 & 71.587 & 84.226 & 89.788 & 90.053 \\
\hline $\mathrm{T}_{11}($ Wheat grain $)$ & 8 & 12 & 37 & 59 & 71 & 83 & 41.709 & 62.69 & 79.803 & 84.454 & 85.996 & 90.887 \\
\hline $\mathrm{T}_{12}$ (Jute bag) & 5 & 11 & 23 & 25 & 27 & 29 & 16.684 & 28.842 & 32.356 & 59.656 & 78.552 & 81.143 \\
\hline $\mathrm{T}_{13}($ Cardamom $)$ & 24 & 41 & 78 & 98 & 115 & 132 & 32.963 & 54.853 & 71.79 & 94.843 & 99.482 & 102.661 \\
\hline SEm \pm & 0.16 & 0.31 & 0.39 & 0.47 & 1.36 & 1.06 & 0.27 & 0.43 & 0.49 & 0.56 & 1.28 & 1.10 \\
\hline $\mathrm{CD}(\mathrm{P}=0.01)$ & 0.46 & 0.89 & 1.12 & 1.35 & 3.88 & 3.03 & 1.04 & 1.66 & 1.90 & 2.17 & 4.90 & 4.20 \\
\hline
\end{tabular}


Table.4 Effect of ripening agent(s) on polygalacturonase (PG) and pectin methyl esterase (PME) content of mango cv. Dhasheri during ripening time

\begin{tabular}{|c|c|c|c|c|c|c|c|c|c|c|c|c|}
\hline \multirow[t]{3}{*}{ Treatment } & \multicolumn{12}{|c|}{ Ripening time (days) } \\
\hline & \multicolumn{6}{|c|}{ Polygalacturonase $(\mathrm{PG})\left(\mu \mathrm{gPGN} \mathrm{min}^{-1}\right)$} & \multicolumn{6}{|c|}{ Pectin methyl esterase (PME) $\left(\mathrm{A}_{620} \mathrm{~min}^{-1}\right)$} \\
\hline & 1 & 2 & 3 & 4 & 5 & 6 & 1 & 2 & 3 & 4 & 5 & 6 \\
\hline $\mathrm{T}_{0}$ (Without treatment) & 2.50 & 2.90 & 3.45 & 4.00 & 4.60 & 4.82 & 0.19 & 0.25 & 0.31 & 0.39 & 0.41 & 0.55 \\
\hline $\mathrm{T}_{1}$ (Ethephon) & 4.45 & 5.12 & 6.65 & 8.82 & 6.45 & 4.58 & 0.39 & 0.45 & 0.55 & 0.76 & 0.43 & 0.39 \\
\hline $\mathrm{T}_{2}$ (Dried plash leaves) & 3.60 & 4.24 & 5.48 & 6.24 & 7.90 & 9.10 & 0.28 & 0.37 & 0.40 & 0.56 & 0.62 & 0.81 \\
\hline $\mathrm{T}_{3}$ (Wet kachnar leaves) & 3.34 & 4.02 & 5.14 & 6.19 & 7.75 & 8.76 & 0.26 & 0.28 & 0.35 & 0.44 & 0.56 & 0.79 \\
\hline $\mathrm{T}_{4}$ (Wet Amaltas leaves) & 3.30 & 3.98 & 5.04 & 6.14 & 7.72 & 8.65 & 0.25 & 0.26 & 0.32 & 0.52 & 0.63 & 0.66 \\
\hline $\mathrm{T}_{5}$ (Wheat straw) & 2.74 & 3.10 & 3.67 & 4.45 & 5.12 & 5.25 & 0.19 & 0.27 & 0.31 & 0.40 & 0.43 & 0.47 \\
\hline $\mathrm{T}_{6}$ (Rice straw) & 2.78 & 3.19 & 3.78 & 4.60 & 5.13 & 5.30 & 0.19 & 0.26 & 0.30 & 0.37 & 0.43 & 0.44 \\
\hline $\mathrm{T}_{7}$ (News paper) & 4.12 & 4.49 & 6.46 & 7.64 & 8.90 & 7.42 & 0.36 & 0.40 & 0.43 & 0.65 & 0.71 & 0.75 \\
\hline $\mathrm{T}_{8}$ (White paper) & 3.05 & 3.98 & 4.12 & 5.14 & 5.67 & 6.12 & 0.30 & 0.35 & 0.39 & 0.49 & 0.58 & 0.60 \\
\hline $\mathrm{T}_{9}$ (Tissue paper) & 3.15 & 4.11 & 4.25 & 5.34 & 5.70 & 6.23 & 0.34 & 0.36 & 0.40 & 0.40 & 0.53 & 0.57 \\
\hline $\mathrm{T}_{10}($ Brown paper bag $)$ & 3.75 & 4.24 & 5.65 & 6.34 & 7.38 & 8.00 & 0.37 & 0.39 & 0.43 & 0.46 & 0.57 & 0.70 \\
\hline $\mathrm{T}_{11}($ Wheat grain $)$ & 3.15 & 3.45 & 3.98 & 4.56 & 5.01 & 5.49 & 0.18 & 0.27 & 0.29 & 0.37 & 0.46 & 0.58 \\
\hline $\mathrm{T}_{12}$ (Jute bag) & 2.52 & 2.91 & 3.44 & 4.01 & 4.71 & 4.84 & 0.17 & 0.24 & 0.30 & 0.35 & 0.43 & 0.57 \\
\hline $\mathrm{T}_{13}$ (Cardamom) & 3.56 & 4.98 & 5.45 & 6.42 & 6.89 & 7.98 & 0.32 & 0.35 & 0.40 & 0.47 & 0.57 & 0.76 \\
\hline SEm \pm & 0.06 & 0.09 & 0.12 & 0.13 & 0.14 & 0.13 & 0.01 & 0.02 & 0.02 & 0.03 & 0.07 & 0.08 \\
\hline $\mathrm{CD}(\mathrm{P}=0.01)$ & 0.08 & 0.11 & 0.13 & 0.15 & 0.36 & 0.34 & 0.06 & 0.09 & .010 & 0.13 & 0.29 & 0.31 \\
\hline
\end{tabular}

\section{Ethylene and respiration rate}

It is evident from the data (Table 3) that ethylene and respiration rate of ripened fruit increased with the advancement of ripening in all the treatments except $\mathrm{T}_{1}$ (Ethephon) treatment where firmness and ripening increases upto $5^{\text {th }}$ day and then decreases. On $6^{\text {th }}$ day of ripening period, maximum ethylene and respiration rate recorded in the $T_{2}$ (dried plash leaves) (151 ppm and $117.846 \mathrm{ml}$ $\mathrm{CO}_{2} \mathrm{~kg}^{-1} \mathrm{~h}^{-1}$ respectively) and minimum in respiration rate in $\mathrm{T}_{1}$ (Ethephon) $(32.528 \mathrm{ml}$ $\left.\mathrm{CO}_{2} \mathrm{~kg}^{-1} \mathrm{~h}^{-1}\right)$ while, minimum ethylene evolution in $\mathrm{T}_{0}$ (Control) treatment (24 ppm). In climacteric fruits sudden increase in respiration and the burst of ethylene production occurs, after which it declines which is the major cause of short shelf life. However, increase in respiration rate and ethylene increases the permeability of the external tissue and enzymatic activity for carotene synthesis and hence hastens the ripening and colour development. The present study was in agreement with (Cua and Lizada, 1990 and Reddy and Srivastava, 1999).

\section{Polygalacturonase (PG) and Pectin methyl esterase (PME)}

The results indicate that the PG and PME of ripened mango increased with the advancement of ripening (Table 4) except in $\mathrm{T}_{1}$ (Ethephon) and $\mathrm{T}_{7}$ (Newspaper). On $6^{\text {th }}$ day maximum PG and PME (9.10 $\mu \mathrm{gPGN}$ $\min ^{-1}$ and $0.81 \mathrm{~A}_{620} \mathrm{~min}^{-1}$ respectively) was recorded in the treatment $\mathrm{T}_{2}$ (Dried plash leaves) and minimum (4.58 $\mu \mathrm{gPGN} \min ^{-1}$ and $\left.0.39 \mathrm{~A}_{620} \mathrm{~min}^{-1}\right)$ was recorded in $\mathrm{T}_{1}$ (Ethephon).

In ripening process Polygalacturonan enzyme produced in plants is involved in hydrolysis of carbohydrates which is the component of the pectin network that comprises plant cell walls. The activity of the endogenous plant polygalacturonase is to soften and sweeten fruit during ripening process. Similarly Pectin methyl esterase is responsible for deestrification of pectin and also to modify $\mathrm{pH}$ and cation exchange properties of wall which might, in turn, affect activity of other wall degrading enzymes. So, increase in PME 
resulted in cell wall softening in mango fruit. The present study is in agreement with (Kalra and Tandon, 1983).

In conclusion, thus, dried plash leaves as ripening agent(s) influence the physicoenzymatic activity of Dashehari mango during ripening period of $6^{\text {th }}$ day, was found best from health point of view and also increase the shelf life of mango during storage as compared other ripening agent(s).

\section{References}

A.O.A.C. 1980. Official Methods of Analysis. Association of official Analytical Chemist, $13^{\text {th }}$ ED, Washington, D.C., USA.

Burg, S.P. and Burg, E.A. 1962. Role of ethylene in fruit ripening. Plant Physiology 37: 179189.

Cua, A.U. and Lizada, M.C. 1990. Ethylene production in the 'Carabao' mango (Mangifera indica L.) fruit during maturation and ripening. Acta Horti., 269:169-179.

Gill, P.S., Jawandha, S.K., Kaur, N. and Verma, A. 2015 Changes in fruit colour of Dushehari mangoes during induced ripening. International J. of Agri., Environment and Biotechnology, 8(1): 97-101

Hagerman, A.E. and Austin, P.J. 1986. Continuous spectrophotometer assay for pectin methyl esterase. J. of Agri. and Food Chemistry, 34: 440-444.

Hernandez-Munoz, P., Almenar, E., Valle, V.D., Velez, D. and Gavara, R. 2008. Effect of chitosan coating combined with postharvest calcium treatment on strawberry (Fragaria xananassa) quality during refrigerated storage. Food Chemistry, 110: 428-435.
Kalra, S.K. and Tandon, D.K. 1983. Ripening behavior of Dashehari mango in relation to harvest period. Scientia Horticulture, 19: 263269.

Karmarkar, D.V. and Joshi, B.M. 1941. Respiration studies of the Alphonso mango. Indian J. of Agri. Sci., 11: 993-1005.

Krishnamurthy, S. and Subramanyam, H. 1970. Respiratory climacteric and chemical changes in the mango fruit (Mangifera indica L.). $J$. American Society of Horti. Sci., 95: 333-337.

Rahaman, A.A. and Bishop, C. 2013. Evaluating the effects of biodegradable and conventional modified atmosphere packaging on the shelflife of organic cavendish bananas. $J$. of Postharvest Techno, 1: 29-35.

Reddy, Y.V. and Shrivastava, G.C. 1999. Ethylene biosynthesis and respiration in mango fruits during ripening. Indian J. of Plant Physiology, 4: 32-35.

Va'squez-Caicedo, A.L., Sruamsiri, P., Carle, R. and Neidhart, S. 2005. Accumulation of all trans-carotene and its 9-cis stereoisomers during postharvest ripening of nine Thai mango cultivars. J. of Agricultural and Food Chemistry, 53: 4827-4835.

Wijewardane, R.M.N.A. 2013. Application of polysaccharide based composite film wax coating for shelf-life extension of guava (var. Bangkok Giant). J. of Postharvest Techno, 1: 16-21.

Yahia, E.M. 2011. Mango (Mangifera indica L.). In: Postharvest Biology and Technology of Tropical and Subtropical Fruits, Woodland Publishing Limited, Cambridge, pp. 492-550.

Zainon, M.A. and Brandy, C.J. 1982. Purification and characterization of polygalacturonase of tomato fruit. Australian J. of Plant Physiology, 9:155-169.

\section{How to cite this article:}

Pramila Kumari, Shalini Pilania, D.K. Sarolia, Virendra Singh, L.N. Mahawer and Seema Gupta. 2017. Influence of Ripening Agent(s) on Post-Harvest Physiology and Enzymatic Activity of Mango (Mangifera indica) cv. Dashehari. Int.J.Curr.Microbiol.App.Sci. 6(12): 3915-3920. doi: https://doi.org/10.20546/ijcmas.2017.612.452 